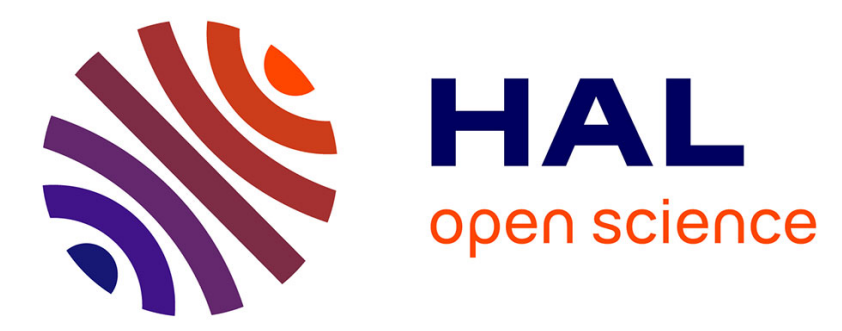

\title{
Controlling charge-transfer properties through a microwave-assisted mono- or bis-annulation of dialkynyl-N-(het)arylpyrroles
}

\author{
Philippe Pierrat, Stéphanie Hesse, Cristina Cebrian, Philippe Gros
}

\section{To cite this version:}

Philippe Pierrat, Stéphanie Hesse, Cristina Cebrian, Philippe Gros. Controlling charge-transfer properties through a microwave-assisted mono- or bis-annulation of dialkynyl-N-(het)arylpyrroles. Organic \& Biomolecular Chemistry, 2017, 15 (40), pp.8568 - 8575. 10.1039/C7OB02149F . hal-01812856

\section{HAL Id: hal-01812856 https://hal.science/hal-01812856}

Submitted on 6 Nov 2018

HAL is a multi-disciplinary open access archive for the deposit and dissemination of scientific research documents, whether they are published or not. The documents may come from teaching and research institutions in France or abroad, or from public or private research centers.
L'archive ouverte pluridisciplinaire HAL, est destinée au dépôt et à la diffusion de documents scientifiques de niveau recherche, publiés ou non, émanant des établissements d'enseignement et de recherche français ou étrangers, des laboratoires publics ou privés. 


\title{
Journal Name
}

\section{ARTICLE}

\section{Controlling charge-transfer properties through a microwave- assisted mono- or bis-annulation of dialkynyl- $\mathrm{N}$-(het)arylpyrroles}

Received 00th January 20xx, Accepted 00th January 20xx

DOI: $10.1039 / x 0 \times x 00000 x$

www.rsc.org/

\author{
Philippe Pierrat, ${ }^{a}$ Stéphanie Hesse, ${ }^{a}$ Cristina Cebrián*a and Philippe C. Gros ${ }^{b}$
}

A selective microwave-assisted mono and bis-annulation of dialkynyl- $N$-(het)arylpyrrole derivatives is described. These polycyclic aromatic hydrocarbons (PAHs) have been photophysical and computationally characterized. The mono-annulated systems display interesting charge-transfer properties. By contrast, these properties vanish within the more conjugated bis-annulated compounds.

\section{Introduction}

Polycyclic aromatic hydrocarbons (PAHs), that could be considered as two-dimensional graphitic moieties, have attracted a huge scientific interest owing to an extraordinary degree of delocalization that opens the way to many applications in material sciences. In this respect, most of the attention is focused on fused molecules with planar geometry such as anthracene, pyrene, coronene, or oligoacene structures, ${ }^{1-3}$ for applications as chromophores, emissive materials and, more generally, in optoelectronics when combined with appropriate semiconductors. Chemical modifications of PAHs (e.g. extension of the delocalization spread, introduction of electron-donating or electronwithdrawing moieties, etc.) are intended to have substantial impact on the HOMO-LUMO energy gap and on the respective location of each frontier orbital within the $\pi$-systems. Moreover, embedding heteroatoms such as oxygen, ${ }^{4}$ boron, ${ }^{5}$ sulfur, ${ }^{6}$ phosphorus ${ }^{7}$ or nitrogen ${ }^{8}$ within the graphitic structure modulates the opto-electronic properties of the molecules, while it also paves the way to PAHs-based organometallic or ionic complexes. ${ }^{2,9}$ Nevertheless, heteroatom-containing polycyclic aromatic hydrocarbons (HPAHs) are still outnumbered by their all-hydrocarbon analogs owing to less common synthetic approaches.

In this respect, $16 \pi$-electron ullazine, which is a nitrogencontaining heterocycle isoelectronic with pyrene, has been the subject of many elegant synthetic strategies reported to date. Following to the first report by Balli et al. in $1983,{ }^{10}$ Kanno et

\footnotetext{
a. Université de Lorraine-Metz \& CNRS, HéCRIn, SRSMC, 1 Boulevard François Arago, 57078 Metz, France. Email : cristina.cebrian-avila@univ-lorraine.fr

b. Université de Lorraine-Nancy \& CNRS, HéCRIn, SRSMC, isE BiBoulevard des

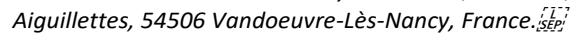

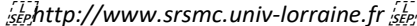

Electronic Supplementary Information (ESI) available: ${ }^{1} \mathrm{H}$ and ${ }^{13} \mathrm{C}-\mathrm{RMN}$ spectra and computational data (detailed procedures and Cartesian coordinates of lowestenergy structures). See DOI: 10.1039/x0xx00000x
}

al. demonstrated a straightforward access to ullazine molecules by reacting organochromium compounds with various alkynes. ${ }^{11}$ In 2012, ${ }^{12}$ the ullazine core was synthesized by a mild Friedel-Crafts intramolecular arylation reaction. One year later, Delcamp et al. have described the synthesis of ullazine-type molecules obtained from a bis(alkyne) derivative mediated by catalytic $\mathrm{InCl}_{3}$ in a double cyclization/hydride shift reaction. ${ }^{13}$ Alternative approaches for ullazine synthesis were reported by using light-mediated ${ }^{14}$ and $\mathrm{Pd}$-catalyzed ${ }^{15}$ two-fold annulation of $\mathrm{N}$-arylpyrroles with alkynes. Fused pyrrole structures can also originate from a 1,3-dipolar cycloaddition of azomethine ylides and various alkenes or akynes. ${ }^{16,17}$ Recently, Boldt et al. reported on the synthesis of aza-ullazine derivatives in a metal-free cyclization promoted by $p$ toluenesulfonic acid for the first time. ${ }^{18}$ However, the presence of an additional nitrogen atom on the periphery did not lead to any noticeable modification of the photophysical properties in comparison with parent ullazine derivatives.
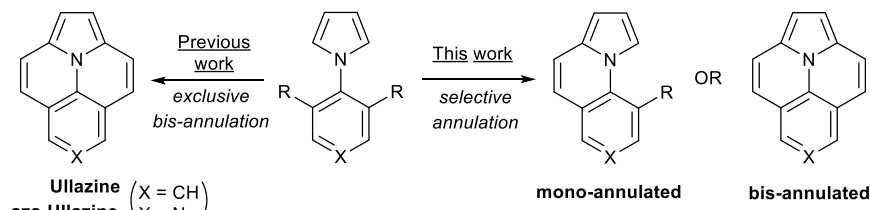
aza-Ullazine $(X=N$

mono-annulated

bis-annulated

Scheme 1. Polycyclic systems resulting from the annulation of dialkynyl- $N$ (het)arylpyrroles.

Apart from its challenging synthesis, ullazine-based compounds are considered to exhibit interesting push-pull properties as shown by a charge-separated mesomeric form upon conjugation of the central pyrrole lone pair within the $\pi$ conjugated system. ${ }^{13}$ However, similarly to most PAHs, nonderivatized (aza-)ullazines present rather apolar photophysical features corresponding mainly to local electronic transitions. ${ }^{10,13,18}$ Nevertheless, a better charge transfer character could be induced by breaking the symmetry of the 
system as it would be, for example, in the case of ullazineprecursor mono-annulated $\mathrm{N}$-(het)arylpyrroles.

In search of chromophores capable to undergo optimal charge transfer (CT) processes to be employed as efficient sensitizers for solar energy applications, we decided to explore the effect of the annulation of dialkynyl- $N$-(het)arylpyrroles 4 on their electronic properties (Scheme 1). Thus, we report herein an expeditious and selective synthetic way to achieve either mono- or bis-annulation of diversely substituted $\mathbf{4}$ under microwave irradiation. These compounds have been photophysically and computationally characterized. We demonstrate the higher CT character of the mono-annulated derivatives when compared with (aza-)ullazines, which can be further improved by the protonation of the pyridine nitrogen in the aza-derivative. As a result, these findings highlight the great potential of the mono-annulated systems as dye sensitizers thanks to highly favorable photophysical features.

\section{Results and discussion}

Starting from amino(het)aryl derivatives $\mathbf{1} \mathbf{a}-\mathbf{b}, \mathbf{d}$, a $\mathrm{S}_{\mathrm{E}} \mathrm{Ar}$ reaction was performed at first in the presence of $N$-bromosuccinimide (NBS) to afford derivatives $\mathbf{2} \mathbf{a}-\mathbf{b}, \mathbf{d}$ in good yields (Scheme 2). Next, compounds 3a-d were efficiently prepared by a ClausonKaas reaction carried out under microwave heating in water for 30 minutes in the absence of any additional catalyst. ${ }^{19}$ Next, a Sonogashira cross-coupling reaction was selected to prepare compounds 4a-c. Previous reports used either $\mathrm{P}\left({ }^{\mathrm{t}} \mathrm{Bu}\right)_{3}{ }^{13}$ or di-1-adamantyl- $n$-butylphosphine $\left(\text { cataCXium }{ }^{\circledR} \mathrm{A}\right)^{18}$ as oxygen sensitive phosphines for 24 hours as reaction time. In our case, we optimized the reaction conditions using standard $\mathrm{PdCl}_{2}\left(\mathrm{PPh}_{3}\right)_{2} / \mathrm{Cul}$ and the less air sensitive $\mathrm{PPh}_{3}$ as catalytic system, together with microwave irradiation as heating source. The target compounds were obtained in good to excellent yields within short reaction times ( $<30$ minutes).

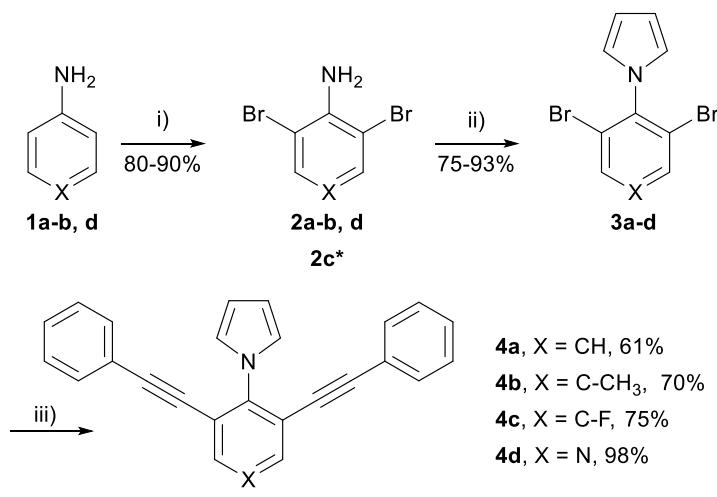

Scheme 2. Synthesis of starting compounds 4 a-d. i) $\mathrm{N}$-bromosuccinimide (2.2 eq.), DMF, r.t, 3h. ii) 2,5-Dimethoxytetrahydrofuran (2 eq.), $\mathrm{H}_{2} \mathrm{O}, \mathrm{MW}, 135^{\circ} \mathrm{C}, 30$ $\mathrm{min}$. In the case of $\mathbf{2 d}$, few drops of acetic acid were necessary to prepare $\mathbf{3 d}$. iii) Alkyne (2.1 eq.), $\mathrm{PdCl}_{2}\left(\mathrm{PPh}_{3}\right)_{2}(10 \%), \mathrm{PPh}_{3}(35 \%)$, Cul (10\%), $\mathrm{Et}_{2} \mathrm{~N}: \operatorname{DMF}(2: 1, \mathrm{v}: \mathrm{v})$, $\mathrm{MW}, 120^{\circ} \mathrm{C}, 30 \mathrm{~min}$. * Commercially available.

We then turned to the annulation step by adapting the reported thermal $\mathrm{InCl}_{3}$-catalyzed cycloisomerization reaction ${ }^{13}$ to microwave heating conditions. Di(alkynes) 4 a-d were thus subjected to reaction with various amounts of $\mathrm{InCl}_{3}$ in $o_{-}$ dichlorobenzene as solvent. We were pleased to observe that the reaction could be done in a selective way, i.e. either allowing the synthesis of mono-annulated compounds $\mathbf{5}$ exclusively or, by increasing the temperature reaction, the bisannulated compounds $\mathbf{6}$. In case of $\mathbf{4 a - c}$, the mono-annulation was achieved after 20 minutes using 0.3 equiv. of indium catalyst at $90^{\circ} \mathrm{C}$, while in case of pyridine derivative $4 \mathrm{~d}$, an increase of the temperature to $160^{\circ} \mathrm{C}$ was required to promote the annulation. This could be explained by the electron withdrawing effect of the $\pi$-deficient pyridine ring on the triple bond (vide infra), that reduces the initial $\eta^{2}$-complex formation upon interaction with the catalyst. ${ }^{20}$ Furthermore, the probable coordination of $\mathrm{InCl}_{3}$ by the pyridine nitrogen required a larger amount of $\mathrm{InCl}_{3}$ (2 equiv.) when compared with aromatic analogues 4a-c. As for the bis-annulation reaction, it was found to be more energy demanding. The aromatic derivatives $6 a-c$ were obtained at $130^{\circ} \mathrm{C}$, while harsher conditions were also needed for the synthesis of the pyridinic derivative $6 \mathbf{d}\left(180^{\circ} \mathrm{C}\right)$.

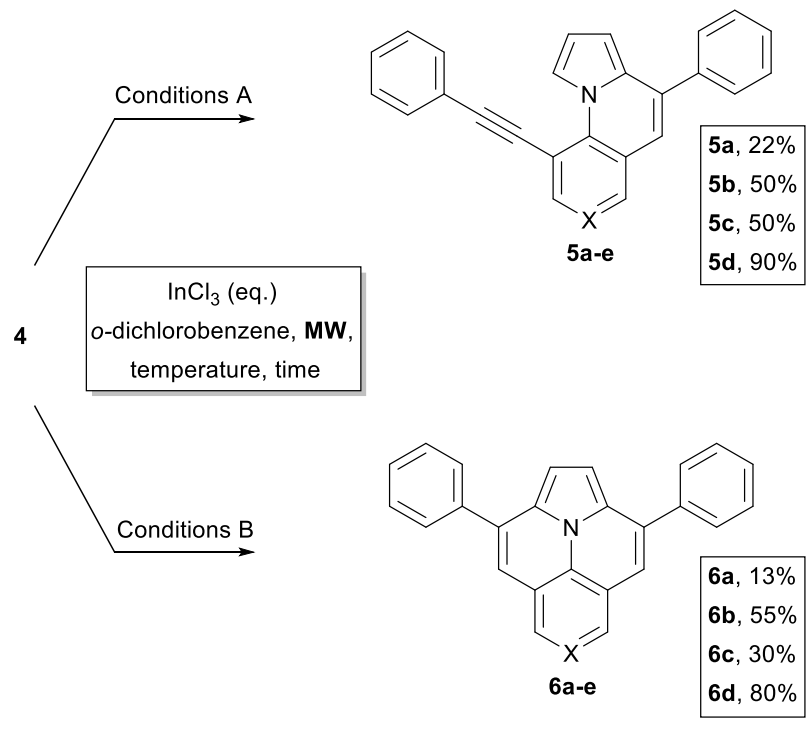

Scheme 3. Conditions $A$ : When $X=C H, C-C_{3}$ and $C-F, \operatorname{lnCl}_{3}\left(0.3\right.$ eq.), $90^{\circ} \mathrm{C}, 20$ $\min$. When $X=N, \operatorname{InCl}_{3}$ (2 eq.), $160^{\circ} \mathrm{C}, 5$ min. Conditions $B$ : When $X=C H, C-C_{3}$ and $\mathrm{C}-\mathrm{F}, \operatorname{InCl}_{3}\left(1\right.$ eq.) $, 130^{\circ} \mathrm{C}, 20 \mathrm{~min}$. When $\mathrm{X}=\mathrm{N}, \operatorname{lnCl}_{3}(3$ eq. $), 180^{\circ} \mathrm{C}, 20 \mathrm{~min}$.

Ground-state $\left(\mathrm{S}_{0}\right)$ structures for compounds $\mathbf{5}$ and $\mathbf{6}$ were optimized by performing density functional theory (DFT) calculations at the PBE0/6-31G(d) level. All calculations were carried out in the presence of solvent (dichloromethane) using the Polarized Continuum Model (PCM) (see ESI for further computational details). Selected geometrical parameters are shown in Fig. S1-S8 and Tables S1-S2 of the ESI. At their lowest-energy geometries, compounds $\mathbf{5}$ exhibit a slightly distorted annulated core with dihedral angles between the pyrrole and the $N$-substituent rings in the range $4.5^{\circ}-6.8^{\circ}$, together with a twist of the phenylacetyl moiety of $11.5^{\circ}-12.9^{\circ}$ with respect to the central core. On the other hand, the monoannulation of the system contributed to place the alpha- 
hydrogen of the pyrrole ring within the deshielding cone of the triple bond, which correlates well with the remarkable downfielded ${ }^{1} \mathrm{H}-\mathrm{NMR}$ chemical shift (ca. $9.5 \mathrm{ppm}$ ) observed for this nucleus. In the case of (aza-)ullazines 6 , the full annulation allows a planarization and symmetrisation of the system.

5d
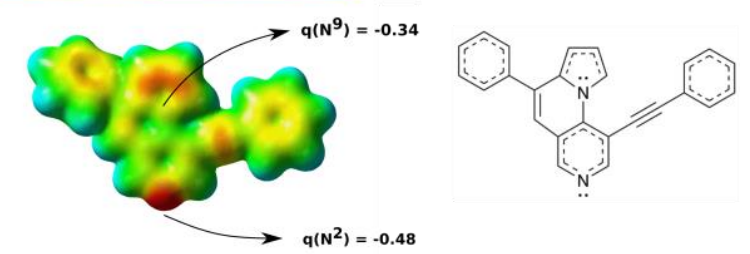

6d
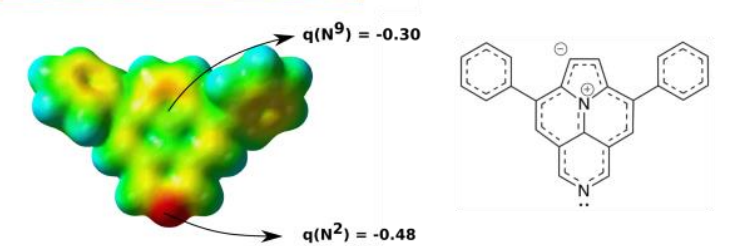

Figure 1. Pictorial representation of the electronic changes on going from mono to bis-annulated systems. Example of the $N$-ullazine derivatives $\mathbf{5 d}$ and $\mathbf{6} \mathbf{d}$. (Left) electrostatic potential projected onto the electron density (isosurface value 0.005 and a range of -0.05 -red- to +0.09 -blue-). (Right) associated molecular resonance forms. Note: the labels were arbitrary attributed.

The differences in electronic conjugation within the central HPAH-core are illustrated in Figure 1 (e.g. 5d and $\mathbf{6 d}$ ). As it can be noticed, the electronic density is particularly localized on the pyrrole and the triple bond moieties, apart from pyridine $\mathrm{N}^{2}$ atom, in the case of mono-annulated compound $\mathbf{5 d}$. Moreover, the presence of a lone pair on the inner nitrogen $\mathrm{N}^{9}$ revealed by a NBO analysis, together with bond distances
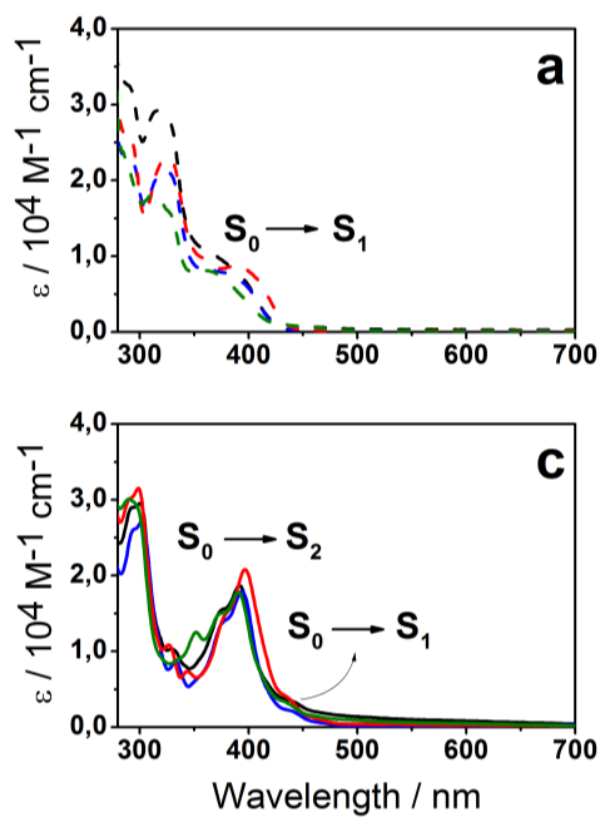

comparable to unsubstituted pyrrole values ${ }^{21}$, indicates that the pyrrolic aromatic system remains independent from the other $\pi$-systems. On the contrary, the electronic current in bisannulated compound $\mathbf{6 d}$ is delocalized on the periphery of the $\mathrm{N}$-ullazine core, with participation of the inner nitrogen to the electronic circulation. ${ }^{10,13}$ Therefore, a more extended and effective $\pi$-conjugation is evident for bis-annulated derivatives 6.

The mono and bis-annulated compounds were characterized by UV-vis absorption and photoluminescence spectroscopy in air-equilibrated $\mathrm{CH}_{2} \mathrm{Cl}_{2}$ solution at room temperature, and the spectra are collected in Figure 2 . To gain deeper insight into the optical properties, these compounds were also investigated at the TD-PBEO(PCM)/6-31+G(d,p) level of theory and the corresponding computational data are summarized in Tables S3-S4 of the ESI. Furthermore, an orbital analysis of the electronic transitions via the calculation of natural transition orbitals (NTOs) ${ }^{22}$ is provided as well. The electronic density can be thus visualized from being transferred from the occupied to the virtual NTO (ONTO and VNTO, respectively), which allows an easy assessment of the nature of the transition (selected orbitals for $\mathbf{5 a - 5 d}$ and $\mathbf{6 a - 6 d}$ are shown in Table 1).

As depicted in Fig. 2 (left), the mono-annulated compounds 5 display intense bands in the UV region ( $\lambda_{\text {abs }} \approx 320 \mathrm{~nm}, \varepsilon>2 \mathrm{x}$ $10^{4} \mathrm{M}^{-1} \mathrm{~cm}^{-1}$ ) that can be ascribed to a localized $\pi-\pi^{*}$ transition, and a less intense $\left(\varepsilon \approx 9 \times 10^{3} \mathrm{M}^{-1} \mathrm{~cm}^{-1}\right)$ and featureless band at 350-450 $\mathrm{nm}$ with intramolecular charge transfer (ICT) character. Going from mono to bis-annulated compounds, the lowest-lying absorption band displays higher intensity $\left(\varepsilon \approx 1.7 \times 10^{4} \mathrm{M}^{-1} \mathrm{~cm}^{-1}\right)$, together with an increased vibronic character that is ascribed to an absorption process
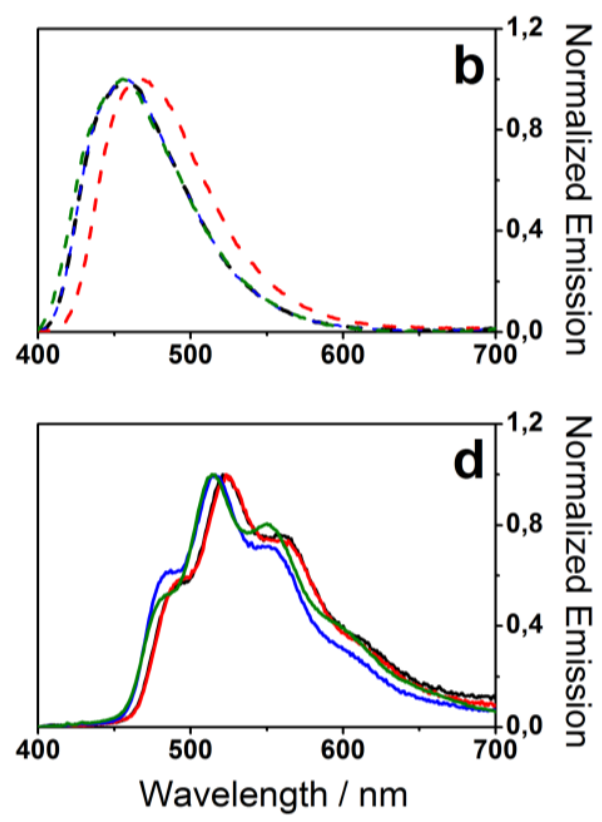

Figure 2. (a) UV-vis absorption and (b) emission $-\lambda_{\text {exc }}=380 \mathrm{~nm}-$ of mono-annulated $\mathbf{5}$ (dashed line). (c) UV-vis absorption and (d) emission $-\lambda_{\text {exc }}=380 \mathrm{~nm}-$ of bisannulated $\mathbf{6}$ (continuous line). All measurements were performed in air-equilibrated dichloromethane solutions at room temperature. Line colors: black $(X=C-H)$, blue $\left(X=C-\mathrm{CH}_{3}\right)$, red $(\mathrm{C}-\mathrm{F})$ and green $(\mathrm{C}=\mathrm{N})$. 
localized on the fused aromatic core.

As far as compounds $\mathbf{5}$ are concerned, the band located at about $390 \mathrm{~nm}$ is assigned to the $\mathrm{S}_{0} \rightarrow \mathrm{S}_{1}$ transition. The corresponding NTOs are differently located along the molecule (Tables 1 and S3). The oNTO is localized mostly on the electron-rich pyrrole moiety together with the vinyl and $N$ substituted ring; while the VNTO is more delocalized, extending up to the phenylalkynyl part of the molecule. These findings clearly show the CT nature of the lowest-lying absorption band. Moreover, it is worth to note that the orbital contribution at the substituted position (i.e. $\mathrm{C}-\mathrm{H}, \mathrm{C}-\mathrm{CH}_{3}, \mathrm{C}-\mathrm{F}$ or $\mathrm{N}$ ) of the central core is more important on the VNTO than on the oNTO, which agrees well with the observed slight red-shift on the low-lying absorption band upon increasing the electronwithdrawing character of the substituent i.e. going from $\mathbf{4 a - 4 b}$ to $\mathbf{4 c - 4 d . ~}$

On the other hand, the more structured band observed at longer wavelength for 6 is attributed to the $S_{0} \rightarrow S_{2}$ transition. The associated NTOs confirm the local $\pi-\pi^{*}$ character since they both similarly reside on the (aza-)ullazine moiety (Tables 1 and S4). The less intense $\left(\varepsilon \approx 3.5 \times 10^{3} \mathrm{M}^{-1} \mathrm{~cm}^{-1}\right)$ shoulder observed at $c a$. $440 \mathrm{~nm}$ is attributable to the symmetryforbidden $S_{0} \rightarrow S_{1}$ transition. ${ }^{23}$ Contrary to their monoannulated counterparts $\mathbf{5}$, an almost identical absorption profile is obtained for compounds 6 regardless of the substitution due to the existence of a nodal plane bisecting the ullazine core. ${ }^{17}$

As shown in Fig. 2 (right), upon irradiation with $\lambda_{\text {exc }}=380$ $\mathrm{nm}$, all compounds 5-6 appeared to be photo-luminescent, although rather different emission features were observed.
Indeed, mono-annulated compounds $\mathbf{5}$ exhibited broad emission profiles typical of CT excited states. In stark contrast, the emission spectrum of bis-annulated compounds 6 is characterized by a structured emission profile corresponding to local $\mathrm{S}_{1} \rightarrow \mathrm{S}_{0}$ transitions.

The presence of a basic peripheral pyridine-like nitrogen atom in derivatives $\mathbf{5} \mathbf{d}$ and $\mathbf{6} \mathbf{d}$ can be of high interest to further tune the optical properties, as for instance by protonation. We

Table 1. NTOs isodensity surfaces for the lowest energy absorption band $(\lambda \approx$

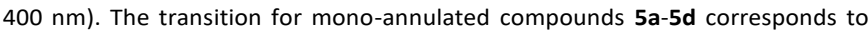
$\mathrm{S}_{0} \rightarrow \mathrm{S}_{1}$ and to $\mathrm{S}_{0} \rightarrow \mathrm{S}_{2}$ for bis-annulated compounds 6a-6d.

Compound oNTO vNTO

$5 a$

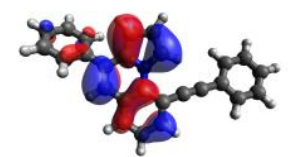

$5 d$
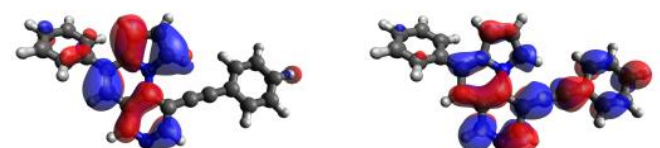

$6 a$

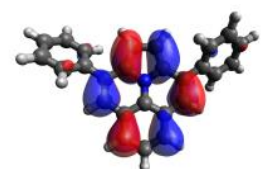

6d
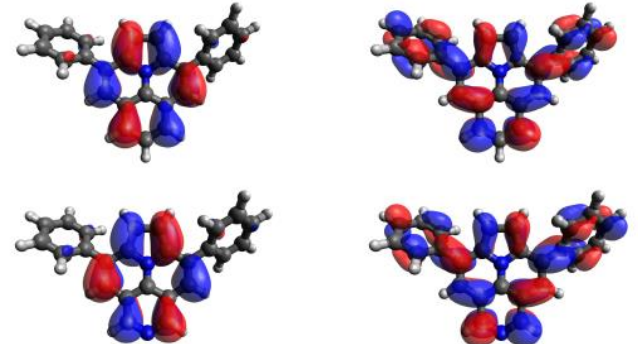
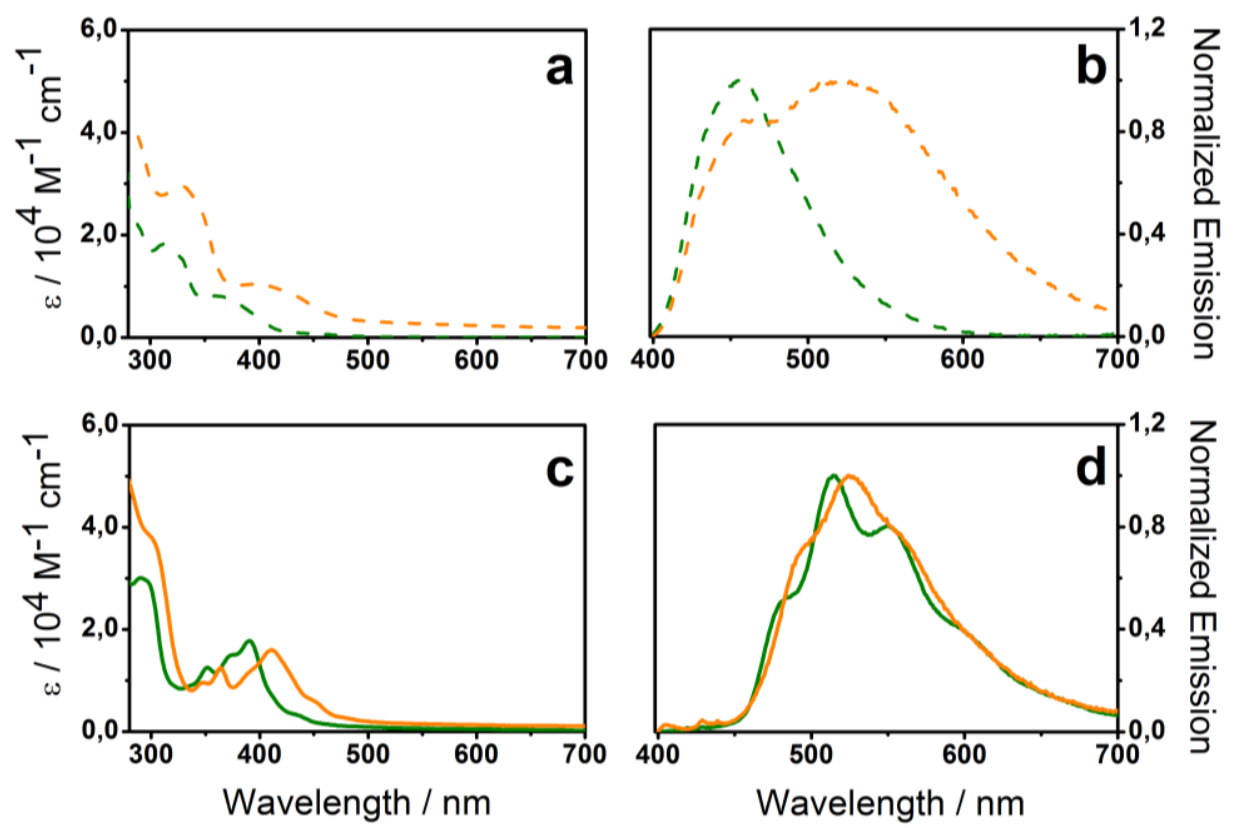

Figure 3. (a) Absorption and (b) emission $-\lambda_{\text {exc }}=380 \mathrm{~nm}-$ spectra of mono-annulated $\mathbf{5 d}$ (dashed green) and $\mathbf{5} \mathbf{d} \cdot \mathrm{H}^{+}$(dashed orange). (c) Absorption and (d) emission $\lambda_{\text {exc }}=380 \mathrm{~nm}$ - spectra of bis-annulated $\mathbf{6 d}$ (green) and $\mathbf{6} \mathbf{d} \cdot \mathrm{H}^{+}$(orange). All measurements were performed in air-equilibrated dichloromethane solutions at room temperature. 
thus performed the protonation of the aza-derivatives $\mathbf{5} \mathbf{d}$ and 6d with triflic acid in $\mathrm{CH}_{2} \mathrm{Cl}_{2}$ at room temperature (Scheme 4). The protonated forms $\mathbf{5} \mathbf{d} \cdot \mathrm{H}^{+}$and $\mathbf{6} \mathbf{d} \cdot \mathrm{H}^{+}$of respectively $\mathbf{5 d}$ and $\mathbf{6 d}$, displayed bathochromic shifts of both absorbance and emission (Fig. 3). The changes in the emission profile are remarkably pronounced for the mono-annulated system (2882 vs. $296 \mathrm{~cm}^{-1}$ for mono- and bis-annulated pairs, respectively) due to the CT, and thus more polar, nature of the involved transition. In contrast, almost no effect is seen for the bisannulated compound.

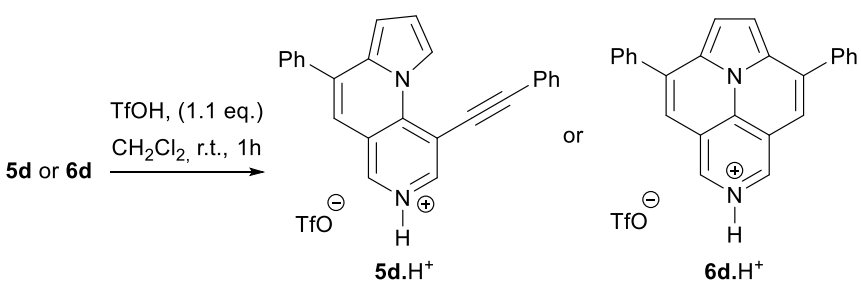

Scheme 4. Synthesis of the pyridynium-like aza-ullazine derivatives $5 \mathbf{d} \cdot \mathrm{H}^{+}$and $6 d \cdot \mathrm{H}^{+}$

\section{Conclusions}

In summary, different heteroatom-containing annulated derivatives from dialkynyl- $N$-(het)arylpyrroles have been described. Capitalizing on an almost full microwave-assisted synthetic sequence, a quick and efficient access to the target compounds was achieved, with the reaction temperature being the key parameter to selectively obtain either mono or bis-annulation. Non-symmetric mono-annulated derivatives showed optically-excited charge-transfer states, as opposed to the symmetric bis-annulated structures that exhibited rather apolar photophysical features. Thus, these results revealed the great potential of the mono-annulated over the bis-annulated systems in optoelectronic applications such as dye-sensitized solar cells (DSSCs).

\section{Experimental}

\section{General}

All solvents were of reagent grade and, when necessary, purified and dried by standard methods. All reactions were routinely checked by TLC analysis on an Alugram SIL G/UV 254 (Macherey-Nagel) with spots visualized by UV light. Melting points were determined in open capillaries on a Stuart SMP3 apparatus and are uncorrected. The ${ }^{1} \mathrm{H}$ and ${ }^{13} \mathrm{C}-\mathrm{NMR}$ spectra were measured on an $\mathrm{AC}$ Bruker $400 \mathrm{MHz}$ spectrometer in $\mathrm{CDCl}_{3}$; chemical shifts are reported in parts per million (ppm). All coupling constants $(J)$ are given in Hz. HRMS spectra were recorded on a Bruker MICROTOF-Q ESI/QqTOF spectrometer. Brominated derivatives $\mathbf{2} \mathbf{a}, \mathbf{2} \mathbf{b}$ and $\mathbf{2 d}$ were prepared according to previously reported procedure. ${ }^{24}$ Pyrroles $\mathbf{3 a} \mathbf{a}^{13}$ $\mathbf{3 b}^{15}$ and $\mathbf{3 d}^{18}$ have been described previously. Sonogashira coupling procedures were adapted from literature. ${ }^{25}$
General procedure for the Clauson-Kaas reaction under microwave heating

Anilines 2a-d (1 eq.) and 2,5-dimethoxytetrahydrofuran (2 eq.) were suspended in water at a concentration of $0.5 \mathrm{M}$ in a 20 $\mathrm{mL}$ glass tube and the reaction vessel was sealed with a Teflon cap. (In case of aniline $\mathbf{2 d}$, few drops of acetic acid were added to the reaction mixture). Microwave irradiation of $60 \mathrm{~W}$ was used, the temperature being ramped to $135^{\circ} \mathrm{C}$, temperature at which the reaction was heated for 35 minutes. The reaction mixture was cooled down to $0^{\circ} \mathrm{C}$ in an ice bath and the precipitated solid was recovered as pure material by filtration.

1-(2,6-dibromo-4-fluoro-phenyl)-1H-pyrrole (3c). This compound was obtained as a brown solid (90\%); $\mathrm{mp}=170-$ $172^{\circ} \mathrm{C}$; ${ }^{1} \mathrm{H}-\mathrm{NMR}\left(400 \mathrm{MHz}, \mathrm{CDCl}_{3}\right) \delta 6.39(\mathrm{t}, 2 \mathrm{H}, J=2.1 \mathrm{~Hz}), 6.66$ $(\mathrm{t}, 2 \mathrm{H}, J=2.1 \mathrm{~Hz}), 7.43\left(\mathrm{~d}, 2 \mathrm{H},{ }^{3} \mathrm{~J}_{\mathrm{H}-\mathrm{F}}=7.3 \mathrm{~Hz}\right) ;{ }^{13} \mathrm{C}-\mathrm{NMR}(100 \mathrm{MHz}$, $\left.\mathrm{CDCl}_{3}\right) \delta 109.5,119.8\left(\mathrm{~d},{ }^{2} \mathrm{~J}=26.4 \mathrm{~Hz}\right), 121.6,124.4$ (d, $\left.{ }^{3} J=11.0 \mathrm{~Hz}\right), 136.6\left(\mathrm{~d},{ }^{4} \mathrm{~J}=4.4 \mathrm{~Hz}\right), 161.2\left(\mathrm{~d},{ }^{1} \mathrm{~J}=259.0 \mathrm{~Hz}\right)$.

\section{General procedure for Sonogashira coupling under microwave heating}

In a dry $10 \mathrm{~mL}$ glass tube diethylamine $(0.75 \mathrm{~mL})$ and $\mathrm{DMF}$ $(0.30 \mathrm{~mL})$ were introduced. The solvent mixture was then degassed by argon bubbling for 15 minutes. Aryl bromide $(0.50$ $\mathrm{mmol}$ ), $\mathrm{PdCl}_{2}\left(\mathrm{PPh}_{3}\right)_{2}$ (38.00 mg, $\left.55.00 \mu \mathrm{mol}\right), \mathrm{Cul}(10.40 \mathrm{mg}$, $55.00 \mu \mathrm{mol})$, triphenylphosphine $(52.00 \mathrm{mg}, 0.19 \mathrm{mmol})$, the alkyne conjugate $(1.10 \mathrm{mmol})$ were introduced and the reaction vessel was sealed with a Teflon cap. Microwave irradiation of $60 \mathrm{~W}$ was used, the temperature being ramped to $120^{\circ} \mathrm{C}$, temperature at which the reaction was heated for 25 minutes. The mixture was then allowed to reach room temperature, filtered through a pad of Celite, washed with ethyl acetate and concentrated to dryness under reduced pressure. The residue was taken up in ethyl acetate $(40 \mathrm{~mL})$. The organic layer was washed with water $(2 \times 40 \mathrm{~mL})$ and sat. $\mathrm{NaCl}(1 \times 40 \mathrm{~mL})$, dried with $\mathrm{MgSO}_{4}$, filtered and concentrated under reduced pressure. The expected compounds were obtained as pure materials after purification on silica flash column chromatography as outlined.

1-[2,6-bis(phenylethynyl)phenyl]-1H-pyrrole (4a). This compound was prepared from 1-(2,6-dibromo-phenyl)- $1 \mathrm{H}$ pyrrole 3a (148 mg, $0.49 \mathrm{mmol}$ ) and phenylacetylene (115 mg, $1.12 \mathrm{mmol})$. After column chromatography with cyclohexane, compound 4a was obtained as a red viscous oil (103 mg, 61\%); ${ }^{1} \mathrm{H}-\mathrm{NMR}\left(400 \mathrm{MHz}, \mathrm{CDCl}_{3}\right) \delta 6.40(\mathrm{t}, 2 \mathrm{H}, \mathrm{J}=2.4 \mathrm{~Hz}), 7.09$ (t, $2 \mathrm{H}$, $J=2.4 \mathrm{~Hz}), 7.30-7.33(\mathrm{~m}, 5 \mathrm{H}), 7.36-7.38(\mathrm{~m}, 6 \mathrm{H}), 7.60(\mathrm{~d}, 2 \mathrm{H}$, $J=7.6 \mathrm{~Hz}) ;{ }^{13} \mathrm{C}$ NMR $\left(100 \mathrm{MHz}, \mathrm{CDCl}_{3}\right) \delta 85.7,93.9,108.4,121.9$, $122.7,122.8,127.1,128.3,128.6,131.6,132.5,143.7$; HRMS (ESI) $\mathrm{m} / \mathrm{z}$ calcd for $\left[\mathrm{C}_{26} \mathrm{H}_{17} \mathrm{~N}+\mathrm{H}\right]^{+} 344.1434$, found 344.1430 .

1-[4-methyl-2,6-bis(phenylethynyl)phenyl]-1H-pyrrole (4b). This compound was prepared from 1-(2,6-dibromo-4-methylphenyl)-1H-pyrrole 3b $(200 \mathrm{mg}, 0.64 \mathrm{mmol})$ and phenylacetylene $(310.0 \mu \mathrm{L}, 2.82 \mathrm{mmol})$. After column chromatography with cyclohexane, compound $\mathbf{4 b}$ was obtained as a yellow viscous oil (158 mg, 70\%); ${ }^{1} \mathrm{H}-\mathrm{NMR}(400$ $\left.\mathrm{MHz} \mathrm{CDCl}_{3}\right) \delta 2.42(\mathrm{~s}, 3 \mathrm{H}), 6.41(\mathrm{t}, 2 \mathrm{H}, J=2.2 \mathrm{~Hz}), 7.09(\mathrm{t}, 2 \mathrm{H}$, $J=2.2 \mathrm{~Hz}), 7.29-7.35(\mathrm{~m}, 6 \mathrm{H}), 7.35-7.41(\mathrm{~m}, 4 \mathrm{H}), 7.43(\mathrm{~s}, 2 \mathrm{H}) ;{ }^{13} \mathrm{C}-$ 
NMR $\left(100 \mathrm{MHz} \mathrm{CDCl}_{3}\right) \delta 20.7,85.9,93.6,108.3,121.5,122.8$ $122.9,128.3,128.5,131.7,133.1,137.1,141.5$; HRMS (APCI) $\mathrm{m} / \mathrm{z}$ calcd for $\left[\mathrm{C}_{27} \mathrm{H}_{19} \mathrm{~N}+\mathrm{H}\right]^{+} 358.1596$, found 358.1565.

1-[4-fluoro-2,6-bis(phenylethynyl)phenyl]-1H-pyrrole (4c). This compound was prepared from 1-(2,6-dibromo-4-fluorophenyl)-1H-pyrrole 3c $(200 \mathrm{mg}, 0.63 \mathrm{mmol})$ and phenylacetylene $(300.0 \mu \mathrm{L}, 2.76 \mathrm{mmol})$. After column chromatography with cyclohexane, compound 4c was obtained as a brown viscous oil (170 mg, 75\%); ${ }^{1} \mathrm{H}-\mathrm{NMR}(400$ $\left.\mathrm{MHz} \mathrm{CDCl}_{3}\right) \delta 6.40(\mathrm{t}, 2 \mathrm{H}, J=2.2 \mathrm{~Hz}), 7.02(\mathrm{t}, 2 \mathrm{H}, J=2.2 \mathrm{~Hz}), 7.33$ (br s, $12 \mathrm{H}) ;{ }^{13} \mathrm{C}-\mathrm{NMR}\left(100 \mathrm{MHz}, \mathrm{CDCl}_{3}\right) \delta 84.7\left(\mathrm{~d},{ }^{4} \mathrm{~J}=3.7 \mathrm{~Hz}\right)$, 94.8, 108.6, 118.9 (d, $2 \mathrm{~J}=24.2 \mathrm{~Hz}), 122.3,122.8,123.7$ (d, ${ }^{3} \mathrm{~J}=11.0 \mathrm{~Hz}$ ), 128.3, 128.9, 131.8, 140.4, 160.5 (d, ${ }^{1} \mathrm{~J}=251.6 \mathrm{~Hz}$ ); HRMS (APCI) $\mathrm{m} / \mathrm{z}$ calcd for $\left[\mathrm{C}_{26} \mathrm{H}_{16} \mathrm{FN}+\mathrm{H}\right]^{+} 362.1345$, found 362.1308.

3,5-bis(phenylethynyl)-4-(1H-pyrrol-1-yl)pyridine (4d). This compound was prepared from 3,5-dibromo-4-(1H-pyrrol-1yl)pyridine 3d (150 $\mathrm{mg}, 0.50 \mathrm{mmol})$ and phenylacetylene (121.0 $\mu \mathrm{L}, 1.10 \mathrm{mmol})$. After column chromatography (cyclohexane/EtOAc, 90/10), compound 4d was obtained as an orange viscous oil (170 mg, 98\%); ${ }^{1} \mathrm{H}-\mathrm{NMR}\left(400 \mathrm{MHz}, \mathrm{CDCl}_{3}\right) \delta$ $6.44(\mathrm{t}, 2 \mathrm{H}, \mathrm{J}=2 \mathrm{~Hz}), 7.32(\mathrm{t}, 2 \mathrm{H}, \mathrm{J}=2 \mathrm{~Hz}), 7.34-7.38(\mathrm{~m}, 6 \mathrm{H}), 7.43$ - $7.48(\mathrm{~m}, 4 \mathrm{H}), 8.76(\mathrm{~s}, 2 \mathrm{H}) ;{ }^{13} \mathrm{C}-\mathrm{NMR}\left(100 \mathrm{MHz}, \mathrm{CDCl}_{3}\right) \delta 83.2$, $96.8,109.6,116.1,122.1,122.2,128.4,129.1,131.6,148.2$, 152.9.

General procedure for monocycloisomerization reaction under microwave heating

A dry $10 \mathrm{~mL}$ glass tube flushed with argon was charged with dialkyne $4 a-c(0.16 \mathrm{mmol})$ and $o$-dichlorobenzene $(1 \mathrm{~mL})$. Then $\mathrm{InCl}_{3} \quad(0.3$ eq. Attention! Reactant highly hygroscopic. Equivalents might be adjusted to full conversion of the initial dialkyne) was introduced rapidly in one portion and the reaction vessel was sealed with a Teflon cap. Microwave irradiation of $60 \mathrm{~W}$ was used, the temperature being ramped to $90^{\circ} \mathrm{C}$, temperature at which the reaction was heated for 20 minutes (for compound $\mathbf{4 d}$ : reaction was performed with 2 equivalents of $\mathrm{InCl}_{3}$ at a temperature of $160^{\circ} \mathrm{C}$ during 5 minutes). The mixture was then allowed to reach room temperature, diluted with $\mathrm{CH}_{2} \mathrm{Cl}_{2}$ and concentrated to dryness under reduced pressure. The residue was purified by column chromatography.

4-phenyl-9-(phenylethynyl)pyrrolo[1,2-a]quinoline (5a). This compound was prepared from 4 a $\left(56 \mathrm{mg}, 0.16 \mathrm{mmol}\right.$ ) and $\mathrm{InCl}_{3}$ (13 mg, $59 \mu \mathrm{mol}, 0.36 \mathrm{eq}$ ). After column chromatography (cyclohexane), compound $\mathbf{5 a}$ was obtained as a red oil (12 mg, 22\%); ${ }^{1} \mathrm{H}-\mathrm{NMR}\left(400 \mathrm{MHz}, \mathrm{CDCl}_{3}\right.$ ) $\delta 6.65$ (dd, $1 \mathrm{H}, J=3.9$ and $1.4 \mathrm{~Hz}), 6.81(\mathrm{dd}, 1 \mathrm{H}, \mathrm{J}=3.9$ and $3.1 \mathrm{~Hz}), 6.95(\mathrm{~s}, 1 \mathrm{H}), 7.29-7.32$ $(\mathrm{m}, 1 \mathrm{H}), 7.42-7.53(\mathrm{~m}, 6 \mathrm{H}), 7.66-7.68(\mathrm{~m}, 3 \mathrm{H}), 7.73-7.76(\mathrm{~m}$, $3 \mathrm{H}), 9.61(\mathrm{dd}, 1 \mathrm{H}, \mathrm{J}=3$ and $1.5 \mathrm{~Hz}) ;{ }^{13} \mathrm{C}-\mathrm{NMR}\left(100 \mathrm{MHz}, \mathrm{CDCl}_{3}\right) \delta$ $89.5,95.4,103.5,110.8,112.0,117.6,118.0,123.1,123.2$, $125.9,128.2,128.4,128.6$ (2C), 128.7, 129.4, 131.3, 131.9, $132.6,133.3,134.3,138.8$.

7-methyl-4-phenyl-9-(phenylethynyl)pyrrolo[1,2a]quinoline (5b). This compound was prepared from $\mathbf{4 b}$ (40 $\mathrm{mg}, 0.11 \mathrm{mmol}$ ) and $\mathrm{InCl}_{3}(7 \mathrm{mg}, 34 \mu \mathrm{mol}, 0.3 \mathrm{eq})$. After column chromatography with cyclohexane, compound $\mathbf{5 b}$ was obtained as a yellow solid (20 mg, 50\%); mp: $135-136^{\circ} \mathrm{C} ;{ }^{1} \mathrm{H}$ NMR $\left(400 \mathrm{MHz} \mathrm{CDCl}_{3}\right) \delta 2.46(\mathrm{~s}, 3 \mathrm{H}), 6.63(\mathrm{dd}, 1 \mathrm{H}, J=3.8$ and $1.3 \mathrm{~Hz}), 6.79(\mathrm{t}, 1 \mathrm{H}, J=3.5 \mathrm{~Hz}), 6.90(\mathrm{~s}, 1 \mathrm{H}), 7.33-7.54(\mathrm{~m}, 7 \mathrm{H})$, $7.58(\mathrm{~d}, 1 \mathrm{H}, J=1.8 \mathrm{~Hz}), 7.66(\mathrm{dd}, 2 \mathrm{H}, J=7.8$ and $1.8 \mathrm{~Hz}), 7.72(\mathrm{~m}$, $2 \mathrm{H}), 9.56(\mathrm{dd}, 1 \mathrm{H}, J=3$ and $1.3 \mathrm{~Hz}) ;{ }^{13} \mathrm{C}-\mathrm{NMR}\left(100 \mathrm{MHz}, \mathrm{CDCl}_{3}\right) \delta$ 20.5, 89.6, 94.9, 103.3, 110.5, 111.7, 117.4, 117.9, 123.3, $125.8,128.1,128.4,128.5,128.6,128.7,129.6,131.3,131.8$, 132.0, 132.6, 133.2, 135.1, 138.9; HRMS (APCI) m/z calcd for $\left[\mathrm{C}_{27} \mathrm{H}_{19} \mathrm{~N}+\mathrm{H}\right]^{+}$358.1596; found 358.1592.

\section{7-fluoro-4-phenyl-9-(phenylethynyl)pyrrolo[1,2-a]quinoline}

(5c). This compound was prepared from 4c (100 mg, 0.28 $\mathrm{mmol}$ ) and $\mathrm{InCl}_{3}(19 \mathrm{mg}, 84 \mu \mathrm{mol}, 0.30 \mathrm{eq})$. After column chromatography with cyclohexane, compound $\mathbf{5 c}$ was obtained as a yellow solid (50 mg, 50\%); mp: $127-129^{\circ} \mathrm{C} ;{ }^{1} \mathrm{H}-$ NMR $\left(400 \mathrm{MHz}, \mathrm{CDCl}_{3}\right) \delta 6.39(\mathrm{t}, 2 \mathrm{H}, J=2.1 \mathrm{~Hz}), 7.01(\mathrm{t}, 2 \mathrm{H}$, $J=2.1 \mathrm{~Hz}), 7.29-7.37(\mathrm{~m}, 12 \mathrm{H}) ;{ }^{13} \mathrm{C}-\mathrm{NMR}\left(100 \mathrm{MHz}, \mathrm{CDCl}_{3}\right) \delta 88.4$ $\left(d,{ }^{4} J=2.93 \mathrm{~Hz}\right), 96.2,104.1,112.1,112.4\left(\mathrm{~d},{ }^{3} \mathrm{~J}=9.5 \mathrm{~Hz}\right), 114.6(\mathrm{~d}$, ${ }^{2} J=22.8 \mathrm{~Hz}$ ), $117.2\left(\mathrm{~d},{ }^{4} J=2.93 \mathrm{~Hz}\right), 117.7,120.5(\mathrm{~d}, 2 J=22.8 \mathrm{~Hz})$, $122.7,127.4(\mathrm{~d}, 3 \mathrm{~J}=9.5 \mathrm{~Hz}), 128.4,128.4,128.6,128.7,128.9$, 129.1, 129.6, 131.4, 132.1, 138.1, 160.4 (d, ${ }^{1} \mathrm{~J}=248.0 \mathrm{~Hz}$ ); HRMS (APCl) $\mathrm{m} / \mathrm{z}$ calcd for $\left[\mathrm{C}_{26} \mathrm{H}_{16} \mathrm{FN}+\mathrm{H}\right]^{+} 362.1345$, found 362.1272 .

6-phenyl-1-(phenylethynyl)pyrrolo[1,2-a][1,6]naphthyridine

(5d). This compound was prepared from 4 d $(50 \mathrm{mg}, 0.15$ $\mathrm{mmol}$ ) and $\mathrm{InCl}_{3}(64 \mathrm{mg}, 0.29 \mathrm{mmol}, 2 \mathrm{eq}$ ). After column chromatography (cyclohexane/ethyl acetate, 95/5), compound $\mathbf{5 d}$ was obtained as a yellow solid (46 mg, 90\%); mp: $82-84^{\circ} \mathrm{C}$; ${ }^{1} \mathrm{H}-\mathrm{NMR}\left(400 \mathrm{MHz}, \mathrm{CDCl}_{3}\right) \delta 6.72(\mathrm{dd}, 1 \mathrm{H}, J=3.9$ and $1.4 \mathrm{~Hz}$ ), $6.87(\mathrm{dd}, 1 \mathrm{H}, J=3.8$ and $3.0 \mathrm{~Hz}), 6.98(\mathrm{~s}, 1 \mathrm{H}), 7.46(\mathrm{~m}, 6 \mathrm{H}), 7.70$ $(\mathrm{m}, 4 \mathrm{H}), 8.79(\mathrm{~s}, 1 \mathrm{H}), 8.84(\mathrm{~s}, 1 \mathrm{H}), 9.48(\mathrm{dd}, 1 \mathrm{H}, J=3.0$ and 1.3 $\mathrm{Hz}) ;{ }^{13} \mathrm{C}-\mathrm{NMR}\left(100 \mathrm{MHz}, \mathrm{CDCl}_{3}\right) \delta 86.3,97.5,105.0,113.7$, $114.9,117.6,120.6,122.5,128.3,128.6,128.7,128.9,129.1$, $129.2,131.5,132.2,135.1,136.5,138.1,149.6,152.4$; HRMS (ESI) $\mathrm{m} / \mathrm{z}$ calcd for $\left[\mathrm{C}_{25} \mathrm{H}_{16} \mathrm{~N}_{2}+\mathrm{H}\right]^{+} 345.1386$, found 345.1399 .

General procedure for biscycloisomerization reaction under microwave heating

A dry $10 \mathrm{~mL}$ glass tube flushed with argon was charged with dialkyne 4a-c $(0.20 \mathrm{mmol})$ and o-dichlorobenzene $(1 \mathrm{~mL})$. Then $\mathrm{InCl}_{3}$ (1-2 eq. Attention! Highly hygroscopic. Equivalents might be adjusted to full conversion of the initial dialkyne) was introduced rapidly in one portion and the reaction vessel was sealed with a Teflon cap. Microwave irradiation of 60W was used, the temperature being ramped to $130^{\circ} \mathrm{C}$, temperature at which the reaction was heated for 20 minutes (for compound $4 \mathrm{~d}$ : reaction was performed with 3 equivalents of $\mathrm{InCl}_{3}$ at a temperature of $180^{\circ} \mathrm{C}$ for 20 minutes). The mixture was then allowed to reach room temperature, diluted with $\mathrm{CH}_{2} \mathrm{Cl}_{2}$ and concentrated to dryness under reduced pressure. The residue was purified by column chromatography.

3,9-diphenylindolizino[6,5,4,3,ija]quinolone (6a). This compound was prepared from 4 a (70 $\mathrm{mg}, 0.20 \mathrm{mmol}$ ) and $\mathrm{InCl}_{3}$ (90 $\mathrm{mg}, 0.40 \mathrm{mmol}, 2 \mathrm{eq}$ ). After column chromatography (cyclohexane), compound 6a was obtained as a red solid (9 $\mathrm{mg}, 13 \%) ; \mathrm{mp}: 173-175{ }^{\circ} \mathrm{C}\left(\right.$ litt $\left.^{10}: 171-175^{\circ} \mathrm{C}\right) ;{ }^{1} \mathrm{H}-\mathrm{NMR}(400$ $\left.\mathrm{MHz}, \mathrm{CDCl}_{3}\right) \delta 7.07(\mathrm{~s}, 2 \mathrm{H}), 7.24(\mathrm{~s}, 2 \mathrm{H}), 7.41-7.55(\mathrm{~m}, 9 \mathrm{H})$, 
7.80-7.82 (m, 4H); ${ }^{13} \mathrm{C}-\mathrm{NMR}\left(100 \mathrm{MHz}, \mathrm{CDCl}_{3}\right) \delta$ 106.0, 119.3, $119.5,123.8,125.8,126.8,128.2,128.3,128.7,132.6,133.5$ 138.7; HRMS (ESI) $\mathrm{m} / \mathrm{z}$ calcd for $\left[\mathrm{C}_{26} \mathrm{H}_{17} \mathrm{~N}\right]^{+} 343.1356$, found 343.1355

6-methyl-3,9-diphenylindolizino $[6,5,4,3$, ija]quinolone

(6b). This compound was pre pared from $4 \mathbf{b}(70 \mathrm{mg}, 0.20 \mathrm{mmol}$ ) and $\mathrm{InCl}_{3}$ (90 mg, $0.40 \mathrm{mmol}, 2 \mathrm{eq}$ ). After column chromatography using with cyclohexane as eluent, compound $\mathbf{6 b}$ was obtained as a yellow solid (38 mg, 55\%); mp: $188-190{ }^{\circ} \mathrm{C} ;{ }^{1} \mathrm{H}-\mathrm{NMR}(400$ $\left.\mathrm{MHz} \mathrm{CDCl}_{3}\right) \delta 2.56(\mathrm{~s}, 3 \mathrm{H}), 7.04(\mathrm{~s}, 2 \mathrm{H}), 7.18(\mathrm{~s}, 2 \mathrm{H}), 7.31(\mathrm{~s}$, $2 \mathrm{H})$, 7.45-7.49 (m, 2H), 7.52-7.56 (m, $4 \mathrm{H}), 7.79-7.82(\mathrm{~m}, 4 \mathrm{H})$; ${ }^{13} \mathrm{C}-\mathrm{NMR}\left(100 \mathrm{MHz}, \mathrm{CDCl}_{3}\right) \delta 21.8,105.8,119.1,120.1,125.8$, 126.6, 128.2 (2C), 128.7 (2C), 131.0, 133.5, 138.9; HRMS (APCI) $\mathrm{m} / \mathrm{z}$ calcd for $\left[\mathrm{C}_{27} \mathrm{H}_{19} \mathrm{~N}\right]+358.1596$, found 358.1594 .

6-fluoro-3,9-diphenylindolizino[6,5,4,3,ija]quinolone (6c). This compound was prepared from $4 \mathrm{c}\left(44 \mathrm{mg}, 0.12 \mathrm{mmol}\right.$ ) and $\mathrm{InCl}_{3}$ ( $27 \mathrm{mg}, 0.12 \mathrm{mmol}, 1 \mathrm{eq}$ ). After column chromatography using cyclohexane as eluent, compound $6 \mathrm{c}$ was obtained as a yellow solid (13 mg, 30\%); mp: $161-163^{\circ} \mathrm{C} ;{ }^{1} \mathrm{H}-\mathrm{NMR}\left(400 \mathrm{MHz}, \mathrm{CDCl}_{3}\right.$ ) $\delta 7.12(\mathrm{~s}, 2 \mathrm{H}), 7.18\left(\mathrm{~d}, 2 \mathrm{H}, 3^{3} \mathrm{H}_{-\mathrm{F}}=9.6 \mathrm{~Hz}\right), 7.22(\mathrm{~s}, 2 \mathrm{H}), 7.47-7.57$ $(\mathrm{m}, 6 \mathrm{H}), 7.80(\mathrm{~d}, 4 \mathrm{H}, J=8 \mathrm{~Hz}) ;{ }^{13} \mathrm{C}-\mathrm{NMR}\left(100 \mathrm{MHz}, \mathrm{CDCl}_{3}\right) \delta 105.3$ (d, $\left.{ }^{2} \mathrm{~J}=24.9 \mathrm{~Hz}\right), 106.8$ (d, $\left.{ }^{4} \mathrm{~J}=2.9 \mathrm{~Hz}\right), 118.7$ (d, $\left.{ }^{4} \mathrm{~J}=2.9 \mathrm{~Hz}\right), 126.6$, 127.3 (d, $\left.{ }^{3} \mathrm{~J}=11.0 \mathrm{~Hz}\right), 128.3,128.5,128.8,129.4,134.6,138.3$, $159.6\left(d,{ }^{1} \mathrm{~J}=243.5 \mathrm{~Hz}\right)$; HRMS $(\mathrm{APCl}) \mathrm{m} / \mathrm{z}$ calcd for $\left[\mathrm{C}_{26} \mathrm{H}_{16} \mathrm{FN}\right]^{+}$ 362.1345 , found 362.1309 .

5,8-diphenylindolizino[6,5,4,3-ija][1,6]naphthyridine (6d). This compound was prepared from $4 \mathbf{d}\left(50 \mathrm{mg}, 0.15 \mathrm{mmol}\right.$ ) and $\mathrm{InCl}_{3}$ (99 mg, $0.45 \mathrm{mmol}, 3 \mathrm{eq}$ ). After column chromatography with (cyclohexane/ethyl acetate, 80/20) as eluent, compound $\mathbf{6 d}$ was obtained as an orange solid (41 mg, 80\%); mp: $193-195^{\circ} \mathrm{C}$ (litt $\left.{ }^{18}: 191-192^{\circ} \mathrm{C}\right) ;{ }^{1} \mathrm{H}-\mathrm{NMR}\left(400 \mathrm{MHz}, \mathrm{CDCl}_{3}\right) \delta 7.19(\mathrm{~s}, 2 \mathrm{H})$, $7.29(\mathrm{~s}, 2 \mathrm{H}), 7.53(\mathrm{~m}, 6 \mathrm{H}), 7.79(\mathrm{~m}, 4 \mathrm{H}), 8.79(\mathrm{~s}, 2 \mathrm{H}) ;{ }^{13} \mathrm{C}-\mathrm{NMR}$ $\left(100 \mathrm{MHz}_{1} \mathrm{CDCl}_{3}\right) \delta 107.8,116.0,120.6,127.0,128.2,128.9$, 129.0, 135.0, 135.3, 138.1, 139.7; HRMS (ESI) m/z calcd for $\left[\mathrm{C}_{25} \mathrm{H}_{16} \mathrm{~N}_{2}+\mathrm{H}\right]^{+}$345.1386, found 345.1389.

\section{General procedure for protonation reaction}

Trifluoromethanesulfonic acid (14 $\mu \mathrm{L}, 0.16 \mathrm{mmol})$ was slowly added to a cooled $\left(0^{\circ} \mathrm{C}\right)$ solution of $\mathbf{5 d}$ or $\mathbf{6 d}(50 \mathrm{mg}, 145 \mathrm{Ghol})$ in $\mathrm{CH}_{2} \mathrm{Cl}_{2}(10 \mathrm{~mL})$. After the addition, the reaction mixture was allowed to reach room temperature, and was stirred for further 30 minutes. The volatiles were removed in vacuo and the residue was triturated in diethylether and finally recovered by filtration.

6-phenyl-1-(phenylethynyl)pyrrolo[1,2-a][1,6]naphthyridin-3ium trifluoromethanesulfonate $\left(\mathbf{5 d} \cdot \mathrm{H}^{+}\right)$. Compound $\mathbf{5 d} \cdot \mathrm{H}^{+}$was obtained as a brown solid (52 mg, 73\%); mp: $178-180^{\circ} \mathrm{C} ;{ }^{1} \mathrm{H}$ NMR $\left(400 \mathrm{MHz} \mathrm{CDCl}_{3}\right) \delta 6.93(\mathrm{dd}, 1 \mathrm{H}, J=3.9$ and $1.1 \mathrm{~Hz}), 7.08(\mathrm{t}$, $1 \mathrm{H}, J=3.8 \mathrm{~Hz}), 7.14(\mathrm{~s}, 1 \mathrm{H}), 7.50(\mathrm{~m}, 6 \mathrm{H}), 7.66(\mathrm{~m}, 4 \mathrm{H}), 8.84(\mathrm{~s}$, $1 \mathrm{H}), 9.14(\mathrm{~s}, 1 \mathrm{H}), 9.57(\mathrm{dd}, 1 \mathrm{H}, J=3.3$ and $1.3 \mathrm{~Hz}), 14.89(\mathrm{~s}, 1 \mathrm{H})$; ${ }^{13} \mathrm{C}-\mathrm{NMR}\left(100 \mathrm{MHz}, \mathrm{CDCl}_{3}\right) \delta 82.4,101.9,108.6,110.0,113.3$, $117.0,119.1,120.5,120.6$ (q, $\left.{ }^{1} \mathrm{~J}=319.1 \mathrm{~Hz}\right), 122.8,128.1,128.8$, 128.9, 129.7, 130.6, 131.7, 132.7, 136.1, 138.6, 139.8, 140.0, 141.2; HRMS (ESI) $\mathrm{m} / \mathrm{z}$ calcd for $\left[\mathrm{C}_{25} \mathrm{H}_{17} \mathrm{~N}_{2}\right]^{+} 345.1386$, found 345.1359 .

5,8-diphenylindolizino[6,5,4,3-ija][1,6]naphthyridin-2-ium trifluoromethanesulfonate $\left(6 \mathrm{~d} \cdot \mathrm{H}^{+}\right)$. Compound $\mathbf{6 d} \cdot \mathrm{H}^{+}$was obtained as a brown solid (57 mg, 80\%); mp: $252-254^{\circ} \mathrm{C} ;{ }^{1} \mathrm{H}$ NMR (400 MHz, $\left.\mathrm{CDCl}_{3}+\mathrm{CD}_{3} \mathrm{OD}\right) \delta 7.53(\mathrm{~m}, 6 \mathrm{H}), 7.60(\mathrm{~s}, 2 \mathrm{H})$, $7.62(\mathrm{~s}, 2 \mathrm{H}), 7.76(\mathrm{~d}, 4 \mathrm{H}, J=8.1 \mathrm{~Hz}), 8.83(\mathrm{~s}, 2 \mathrm{H}) ;{ }^{13} \mathrm{C}-\mathrm{NMR}(100$ $\left.\mathrm{MHz}, \mathrm{CDCl}_{3}+\mathrm{CD}_{3} \mathrm{OD}\right) \delta 112.9,115.6,123.6,128.6,129.0$, 129.8, 130.0, 130.4, 136.9, 137.5, 139.2; HRMS (ESI) m/z calcd for $\left[\mathrm{C}_{25} \mathrm{H}_{17} \mathrm{~N}_{2}\right]^{+} 345.1386$, found 345.1354 .

\section{Conflicts of interest}

There are no conflicts to declare.

\section{Acknowledgements}

The authors would like to thank V. Vaillant for performing NMR spectra, F. Lachaud for mass spectrometry analysis and S. Parant for his help with the optical spectroscopy measuremeants.

\section{Notes and references}

1 M. Watanabe, K.-Y. Chen, Y. J. Chang and T. J. Chow, Acc. Chem. Res., 2013, 46, 1606-1615.

2 J. Wu, W. Pisula and K. Müllen, Chem. Rev., 2007, 107, 718-747.

3 J. E. Anthony, Chem. Rev., 2006, 106, 5028-5048.

4 Some selected examples: (a) C. B. Nielsen, T. Brock-Nannestad, T. K. Reenberg, P. Hammershøj, J. B. Christensen, J. W. Stouwdam and M. Pittelkow, M. Chem. Eur. J., 2010, 16, 1303013034; (b) T. Miletić, A. Fermi, I. Orfanos, A. Avramopoulos, F. De Leo, N. Demitri, G. Bergamini, P. Ceroni, M. G. Papadopoulos, S. Couris and D. Bonifazi, Chem. Eur. J., 2017, 23, 2363-2378.

5 Some selected examples: (a) A .Escande and M. J. Ingleson, Chem. Commun., 2015, 51, 6257-6274; (b) V. M. Hertz, J. G. Massoth, M. Bolte, H.-W. Lerner and M. Wagner, Chem. Eur. J., 2016, 22, 13181-13188.

6 Some selected examples: (a) Q. Xiao, T. Sakurai, T. Fukino, K. Akaike, Y. Honsho, A. Saeki, S. Seki, K. Kato, M. Takata and T. Aida, J. Am. Chem. Soc., 2013, 135, 18268-18271; (b) L. Chen, K. S. Mali, S. R. Puniredd, M. Baumgarten, K. Parvez, W. Pisula, S. De Feyter and K. Müllen, J. Am. Chem. Soc., 2013, 135, 1353113537; (c) W. Hagui, N. Besbes, E. Srasra, T. Roisnel, J.-F. Soulé and H. Doucet, Org. Lett., 2016, 18, 4182-4185; (d) L. Meng, T. Fujikawa, M. Kuwayama, Y. Segawa and K. Itami, J. Am. Chem. Soc., 2016, 138, 10351-10355.

7 Some selected examples: (a) P.-A. Bouit, A. Escande, R. Szúcs, D. Szieberth, C. Lescop, L. Nyulászi, M. Hissler and R. Réau, J. Am. Chem. Soc., 2012, 134, 6524-6527; (b) W. Delaunay, R. Szűcs, S. Pascal, A. Mocanu, P.-A. Bouit, L. Nyulászi and M. Hissler, Dalton Trans., 2016, 45, 1896-1903; (c) P. Hindenberg, A. LópezAndarias, F. Romiger, A. de Cózar and C. Romero-Nieto, Chem. Eur. J. 10.1002/chem.201701649.

8 Some selected examples: (a) J. Wei, B. Han, Q. Guo, X. Shi, W. Wang and N. Wei, Angew. Chem. Int. Ed., 2010, 49, 8209-8213. (b) R. Berger, A. Giannakopoulos, P. Ravat, M. Wagner, D. Beljonne, X. Feng and K. Müllen, Angew. Chem. Int. Ed., 2014, 53, 10520-10524; (c) Y. Yang, D. Liu, M. Song, D. Shi, B. Liu, K. Cheng, Y. Lu, H. Liu, M. Yang, W. Wang, J. Li and J. Wei, Chem. Eur. J., 2017, 23, 7409-7413.

9 S. M. Draper, D. J. Gregg, E. R. Schofield, W. R. Browne, M. Duati, J. G. Vos and P. Passaniti, J. Am. Chem. Soc., 2004, 126, 8694-8701.

10 H. Balli and M. Zeller, Helv. Chim. Acta, 1983, 66, 2135-2139. 
11 K. Kanno, Y. Liu, A. lesato, K. Nakajima and T. Takahashi, Org. Lett., 2005, 7, 5453-5456.

12 J. Zhou, W. Yang, B. Wang and H. Ren, Angew. Chem. Int. Ed., 2012, 51, 12293-12297.

13 J. H. Delcamp, A. Yella, T. W. Holcombe, M. K. Nazeeruddin and M. Grätzel, Angew. Chem. Int. Ed., 2013, 52, 376-380.

14 A. Das, I. Ghosh and B. König, Chem. Commun., 2016, 52, 86958698.

15 D. Wan, X. Li, R. Jiang, B. Feng, J. Lan, R. Wang and J. You, Org. Lett., 2016, 18, 2876-2879.

16 S. Ito, Y. Tokimaru and K. Nozaki, Chem. Commun., 2015, 51, 221-224.

17 R. Berger, M. Wagner, X. Feng and K. Müllen, Chem. Sci., 2015, 6, 436-441.

18 S. Boldt, S. Parpart, A. Villinger, P. Ehlers and P. Langer, Angew. Chem. Int. Ed., 2017, 56, 4575-4578.

19 M. A. Wilson, G. Filzen and G. S. Welmaker, Tetrahedron Lett., 2009, 50, 4807-4809.

20 A. Fürstner and V. Mamane, J. Org. Chem., 2002, 67, 62646267.

21 U. Nygaard, J. T. Nielsen, J. Kirchheiner, J. Mol. Structure 1969, 3, 491-506.

22. a) J.-D. Chai and M. Head-Gordon, Phys. Chem. Chem. Phys. 2008, 10, 6615-6620; b) A. Monari, T. Very, J.-L. Rivail and X. Assfeld, Comput. Theor. Chem., 2012, 990, 119-125.

23 (a) M. Irie, T. Kamijo,M. Alkawa, T. Takemura, K. Hayashi, H. Baba, J. Phys. Chem., 1977, 81, 1571-1583 ; (b) O. A. Khakhel, J. Appl. Spectr., 2001, 68, 280-286.

24 M. Müri, K. C. Schuermann, L. De Cola, M. Mayor, Eur. J. Org. Chem., 2009, 2562-2575.

25 M. Erdélyi, A. Gogoll, J. Org. Chem., 2001, 66, 4165-4169. 